\title{
TESTING APLIKASI BUSINESS ACTIVITY MONITORING PADA INTERNET SERVICE PROVIDER MENGGUNAKAN ISO 25010
}

\author{
Charles Martino ${ }^{1)}$, Johanes Fernandes Andry ${ }^{2)}$ \\ ${ }^{1,2}$ Sistem Informasi, Universitas Bunda Mulia \\ ${ }^{1,2}$ Jalan Lodan Raya No. 2, Daerah Khusus Ibukota Jakarta 14430 Indonesia

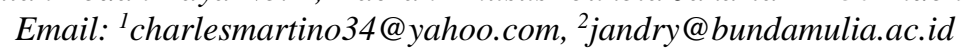

\begin{abstract}
Abstrak
Penggunaan sistem informasi dalam perusahaan sudah menjadi hal yang tidak asing pada zaman sekarang. Sistem informasi banyak digunakan untuk berbagai tujuan, salah satunya untuk mengawasi proses bisnis dalam perusahaan. Sistem yang dapat digunakan untuk mengawasi proses bisnis salah satunya adalah Business Activity Monitoring (BAM). Salah satu perusahaan ISP di Jakarta telah menggunakan BAM yang dibuat oleh tim internalnya. Dalam melakukan pengawasan, sistem yang tidak berkualitas tentu tidak dapat memenuhi kebutuhan perusahaan dan dapat memberikan informasi yang salah yang membawa dampak buruk bagi perusahaan. Maka dari itu, peneliti tertarik untuk melakukan testing terhadap aplikasi BAM dalam perusahaan tersebut untuk mengukur kualitas aplikasi. Metode yang digunakan oleh peneliti dalam melakukan testing adalah studi lapangan dan User Acceptance Test (UAT) dengan standar ISO 25010. Penelitian dibataskan pada karakteristik functional suitability karena adanya batasan waktu dan biaya. Dari hasil testing, ditemukan beberapa ketidaksesuaian antara hasil yang diharapkan dan hasil aktual, beberapa diantaranya memiliki tingkat keparahan yang tinggi. Meskipun aplikasi yang digunakan masih memenuhi kebutuhan perusahaan dalam fungsionalitas utama, aplikasi sebaiknya diperbaiki sesegera mungkin. Penggunaan metode UAT dinilai tepat karena dapat mencakup area yang luas dari karakteristik functional suitability.
\end{abstract}

Kata Kunci: business activity monitoring, functional suitability, ISO 25010, user acceptance test, testing

\section{Pendahuluan}

Sistem informasi merupakan kata yang sudah tidak asing pada era sekarang ini. Sudah banyak sistem informasi yang dibangun untuk membantu berbagai jenis kegiatan manusia [1]. Banyak orang dan perusahaan yang terbantu kegiatannya dengan adanya sistem informasi tersebut, baik secara langsung maupun tidak langsung. Banyak perusahaan menggunakan sistem informasi untuk mendukung kemajuaan usahanya. Sistem informasi tersebut umumnya digunakan untuk meningkatkan performa proses bisnis [2], membantu pengambilan keputusan [3], maupun untuk monitoring berjalannya proses [4].
Salah satu sistem informasi yang dapat digunakan untuk memonitor jalannya proses bisnis adalah Business Activity Monitoring (BAM). BAM dapat memberikan gambaran umum kepada manajer operasional dan manajemen tingkat atas mengenai proses bisnis yang terjadi dalam perusahaan pada saat itu juga atau secara real-time [5].

Monitoring berjalannya proses bisnis merupakan salah satu proses yang penting dalam perusahaan karena dengan adanya proses monitoring, semua proses bisnis yang ada dalam perusahaan menjadi terkendali dan masalah yang timbul sewaktu-waktu dapat diketahui dengan cepat sehingga perusahaan dapat mengambil tindakan sesegera mungkin untuk menyelesaikan masalah tersebut [6].

Pencapaian terhadap tujuan yang diharapkan dari monitoring menggunakan BAM sangatlah bergantung pada kualitas BAM itu sendiri [7]. Kualitas BAM yang rendah tidak akan memberikan value yang ingin dicapai penggunanya. Tidak hanya itu, penggunaan BAM yang berkualitas rendah juga dapat mengurangi niat pengguna untuk memakainya [8], dan berpotensi memiliki dampak negatif seperti menampilkan informasi yang tidak tepat dan dapat mempengaruhi pengambilan keputusan oleh manajemen.

Untuk memastikan kualitas aplikasi, tidak hanya monitoring dan manajemen yang diperlukan, namun juga pemenuhan terhadap standar yang ketat [9]. Pengujian pemenuhan kualitas terhadap suatu standar dan terhadap kebutuhan pengguna dapat dilakukan dengan melakukan software testing.

Salah satu standar yang popular untuk melakukan software testing adalah ISO 9126 karena fleksibilitas dan sifat umumnya [10], [11], namun, standar tersebut kini telah digantikan dengan ISO 25010. ISO 25010 mengelompokan kualitas suatu produk kedalam 8 karakteristik yang masing-masing memiliki beberapa sub-karakteristik [12].

Sebuah perusahaan Internet Service Provider (ISP) yang juga menyediakan berbagai layanan Information and Communication Techonology (ICT) di Jakarta telah melakukan monitoring terhadap proses bisnisnya. Perusahaan tersebut menggunakan web-based BAM yang dibuat oleh tim internalnya.

Penelitian ini dilakukan untuk memastikan aplikasi BAM yang digunakan berkualitas sehingga perusahaan dapat mencapai tujuan yang diharapkan dari penggunaan aplikasi dengan menggunakan standar kualitas produk ISO 25010. 


\section{Tinjauan Pustaka}

A. BAM (Business Activity Monitoring)

BAM adalah sistem yang ditujukan untuk menyediakan informasi secara real-time mengenai status dan hasil dari berbagai operasi, proses, dan transaksi bisnis [5], sehingga manajer dapat mengetahui apa yang sedang terjadi dalam perusahaan dan mengambil keputusan dengan cepat dan efektif [13].

B. ISO 25010

ISO 25010 "System and Software Engineering System and Software Quality Requirements and Evaluation (SQuaRE) - System and Software Quality Models" menggantikan standar ISO 9126 "Software Engineering - Product Quality" sebagai dua model kualitas untuk produk software: kualitas penggunaan dan kualitas produk [14].

Kualitas produk terbagi menjadi menjadi 8 karakteristik yaitu functional suitability, reliability, performance efficiency, usability, security, compatibility, maintainability, dan portability [15]. Definisi dari karakteristik-karakterisitek tersebut adalah:

1) Functional Suitability

Sejauh mana fungsi yang disediakan software dapat memenuhi kebutuhan yang dinyatakan ketika software digunakan dalam kondisi tertentu [16], [17], [18].

2) Performance Efficiency

Sejauh mana software menghasilkan kinerja yang sesuai dengan jumlah sumber daya yang digunakan dalam kondisi yang telah ditetapkan [16], [17], [18], [19].

3) Compability

Kemampuan dua atau lebih komponen software untuk bertukar informasi dan / atau untuk melakukan fungsi yang diperlukan sambil berbagi perangkat keras atau perangkat lunak yang sama [16], [18].

4) Usability

Sejauh mana software mempermudah pengguna dalam mengoperasikan dan mengendalikannya [16], [17], [18].

5) Reliability

Sejauh mana software dapat menjaga tingkat kinerja ketika digunakan dalam kondisi tertentu [16], [17], [18].

6) Security

Keamanan sistem dari akses, penggunaan, modfikasi, perusakan, penyingkapan yang tidak disengaja atau dengan niat jahat [16], [18].

7) Maintainability

Sejauh mana software dapat dimodifikasi. Modifikasi termasuk koreksi, peningkatan, adaptasi terhadap perubahan lingkungan sistem, dan perubahan dalam kebutuhan dan spesifikasi fungsional [16], [17], [18].
8) Portability

Kemudahan dalam pemindahan sistem atai komponen sistem ke lingkungan sistem lainnya (memperluas lingkungan software atau hardware) [16], [17], [18].

C. UAT (User Acceptance Test)

UAT adalah proses memverifikasi suatu solusi berfungsi untuk penggunanya [20]. UAT melibatkan pengguna untuk mengetahui apa yang dilakukan sistem dan apa yang didapatkan pengguna [21]. UAT termasuk ke dalam black-box testing di mana pengguna tidak tertarik dengan bagian internal/coding sistem, namun membandingkan fungsi sistem dengan requirement yang dispesikasikan oleh mereka.

\section{Metode Penelitian}

Tabel 1. Karakteristik dan Sub-karakteristik Kualitas Produk Berdasarkan ISO 25010 [18]

\begin{tabular}{ll}
\hline \multicolumn{1}{c}{ Karakteristik } & \multicolumn{1}{c}{ Sub-karakteristik } \\
\hline \multirow{3}{*}{ Functional Suitability } & Functional Completeness \\
& Functional Correctness \\
& Functional Appropriateness \\
\hline \multirow{3}{*}{ Performance Efficiency } & Time Behavior \\
& Resource Utilization \\
& Capacity \\
\hline \multirow{2}{*}{ Compability } & Co-existence \\
& Interoperability \\
\hline \multirow{5}{*}{ Usability } & Appropriateness \\
& Recognizability \\
& Learnability \\
& Operability \\
& User Error Protection \\
& User Interface Aesthetics \\
& Accessibility \\
\hline \multirow{5}{*}{ Reliability } & Maturity \\
& Availability \\
& Fault Tolerance \\
& Recoverability \\
\hline \multirow{5}{*}{ Security } & Confidentiality \\
& Integrity \\
& Non-repudiation \\
& Accountability \\
& Authenticity \\
\hline \multirow{5}{*}{ Maintainability } & Modularity \\
& Reusability \\
& Analysability \\
& Modifiability \\
& Testability \\
\hline & Adaptibility \\
& Installibility \\
Replaceability \\
\end{tabular}

Metode yang digunakan dalam penelitian ini adalah studi lapangan dan User Acceptance Testing (UAT), sehingga pandangan dan pendapat partisipan penelitian dapat diukur dan dianalisa [9]. UAT sebagai salah satu tipe dari 
acceptance test juga merupakan elemen kunci dalam penggunaan karena pada dasarnya software haruslah layak untuk pemilik atau penggunanya [22].

Standar yang digunakan dalam penelitian ini adalah ISO 25010 pada kualitas produk. Tabel 1 menunjukkan karakteristik dan sub-karakteristik dari standar kualitas produk ISO 25010.

Penelitian difokuskan hanya pada satu karakteristik karena adanya keterbatasan waktu dan biaya. Karakteristik yang digunakan adalah functional suitability, yaitu apakah fungsi-fungsi yang dimiliki produk dapat memenuhi kebutuhan penggunanya, karena tujuan utama dari penelitian ini adalah untuk memastikan BAM dapat menjalankan fungsinya dan menghasilkan informasi yang tepat dan sesuai kebutuhan.

Karakteristik ini terbagi menjadi tiga subkarakteristik, yaitu functional completeness (F1), functional correctness (F2), functional appropriateness (F3). F1 mengukur cakupan fungsi-fungsi yang ada terhadap tugasnya dan kebutuhan pengguna. F2 mengukur ketepatan hasil dari sistem. F3 mengukur kelayakan fungsi dalam menyelesaikan tugasnya.

\section{Hasil dan Pembahasan}

Aplikasi BAM yang digunakan perusahaan saat ini terdiri dari beberapa modul, yaitu:

- Modul Master

- Modul Project Bisnis

- Modul Penugasan

- Modul Laporan

- Modul Pengguna

Modul master berfungsi untuk mengelola data master, yang meliputi pengguna, divisi, jabatan, cabang, client, jenis client, kota, prioritas, template email, project, task, dan hak akses. Master pengguna berisi data karyawan perusahaan yang merupakan pengguna aplikasi. Master divisi berisi data divisi seperti nama dan kode transaksi. Master jabatan berisi tingkatan atau kedudukan karyawan dalam suatu divisi. Master cabang berisi data anak perusahaan dari perusahaan yang akan menggunakan aplikasi. Master client berisi data client atau pelanggan yang membuat permintaan layanan. Master jenis client berisi jenis dari perusahaan client atau kata sapaan untuk client non-perusahaan. Master kota berisi data kota dari client. Master prioritas berisi tingkat prioritas dari proses. Master template email berisi data template email yang akan dikirimkan ke client. Master project berisi data mengenai project dan task yang ada didalamnya. Master task berisi data task yang merupakan bagian dari suatu project. Master hak akses berisi kategori pengguna yang digunakan untuk membatasi akses pengguna.

Modul project bisnis dan modul penugasan merupakan modul operasional dari aplikasi. Alur kerja dari kedua modul ini dapat dilihat dalam flowchart yang ditunjukan pada Gambar 1. Modul project bisnis dijalankan terlebih dahulu yang dapat dilihat pada bagian atas flowchart, kemudian dilanjutkan dalam modul penugasan yang berada di bagian bawah flowchart.
Modul project bisnis memiliki tahapan sebagai berikut: validasi client, pembuatan project baru, dan validasi project. Client yang sudah divalidasi dapat dipilih ketika membuat project baru. Project baru adalah proses yang dilakukan karena adanya permintaan dari client. Project yang sudah dibuat harus divalidasi terlebih dahulu. Jika project yang sudah divalidasi, maka task dari project itu akan ditugaskan kepada divisi yang bertanggung jawab terhadap task itu dan akan ada email yang dikirimkan kepada client berdasarkan template yang sudah dibuat.

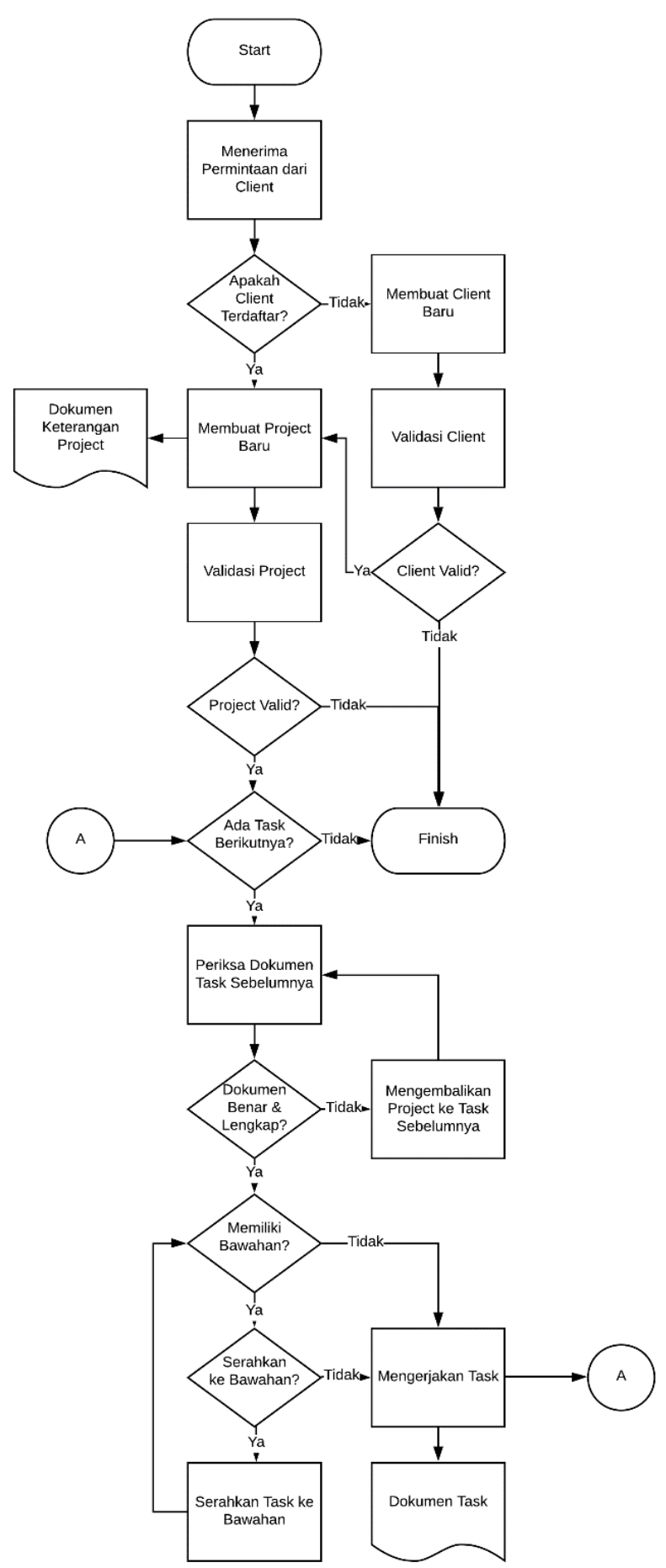

Gambar 1. Flowchart Aplikasi BAM 
Modul penugasan terbagi menjadi beberapa bagian, namun kegiatan utama pada modul ini adalah pemilihan karyawan yang ditugaskan, pengerjaan task, dan chat. Ketika suatu divisi menerima task, task tersebut akan pertama kali ditugaskan kepada manajer divisi. Manajer divisi kemudian dapat menugaskan task tersebut kepada salah satu bawahannya. Bawahannya juga dapat menyerahkan task tersebut ke bawahannya atau karyawan lain yang memiliki jabatan yang sama, jika ada. Task yang sudah diterima dapat dikerjakan dengan mengunggah dokumen task (jika ada) ke aplikasi dan menyerahkan project ke divisi berikutnya. Pengguna dapat melihat dokumen-dokumen yang diunggah oleh divisi sebelumnya pada bagian history. Jika task yang diterima tidak memiliki dokumen yang benar atau lengkap dari task sebelumnya, maka task dapat ditolak dan dikembalikan ke divisi sebelumnya untuk diperbaiki. Dalam menjalankan task, pengguna juga dapat berkomunikasi dengan semua pengguna yang terlibat dalam project itu dengan fitur chat, baik untuk meminta keterangan, menyampaikan pemberitahuan, ataupun halhal lainnya yang berhubungan dengan project.

Bagian-bagian pada modul penugasan secara lengkap adalah history, chat, assigned to me, waiting list, on progress, dan resolved activty. Di bagian history, pengguna dapat melihat task-task sebelumnya dari project yang sedang dikerjakan. Untuk setiap task pada history, pengguna dapat melihat pengguna yang mengerjakan berserta divisi dan jabatannya, waktu task dimulai dan diselesaikan, Service Level Agreement (SLA) untuk task tersebut, dan dokumen-dokumen yang diunggah. Pada assigned to me, pengguna dapat melihat task-task yang telah ditugaskan kepadanya. Pada waiting list, pengguna dapat melihat task-task mungkin akan ditugaskan kepadanya. Task-task yang mungkin ditugaskan kepada seorang pengguna adalah task-task yang dimiliki oleh atasannya, dan jika pengguna memiliki jabatan sebagai manajer, maka akan bagian ini akan berisi project-project yang belum tervalidasi dan divisinya merupakan yang bertanggung jawab untuk task berikutnnya dalam project tersebut. Pada on progress, pengguna dapat melihat task-task yang sudah diselesaikan olehnya namun masih dikerjakan divisi lain. Pada resolved activity, pengguna dapat melihat task-task yang sudah selesai. Pada bagian assigned to me, waiting list, dan on progress; pengguna juga dapat mengekspor task-task tersebut ke bentuk excel.

Tabel 2. Test Case yang Tidak Terpenuhi pada Sub-karakteristik F2 dalam Modul Project bisnis dan Penugasan

\begin{tabular}{|c|c|c|c|c|c|}
\hline Test Case & Pre-condition & Test Step & Expected Result & Actual Result & Severity \\
\hline $\begin{array}{l}\text { Validasi } \\
\text { client } \text { oleh } \\
\text { non-admin }\end{array}$ & $\begin{array}{l}\text { - Pengguna bukan dari } \\
\text { divisi admin } \\
\text { - Pengguna sudah berada di } \\
\text { halaman master client } \\
\text { - Ada data client yang } \\
\text { belum divalidasi }\end{array}$ & $\begin{array}{l}\text { 1. Klik tombol } \\
\text { Validate pada client } \\
\text { yang belum } \\
\text { tervalidasi }\end{array}$ & $\begin{array}{l}\text { Muncul pesan } \\
\text { "Only admins can } \\
\text { validate client." }\end{array}$ & $\begin{array}{l}\text { Muncul kotak } \\
\text { konfirmasi, dan } \\
\text { client tervalidasi } \\
\text { jika dikonfirmasi }\end{array}$ & High \\
\hline $\begin{array}{l}\text { Menyerahkan } \\
\text { tugas kepada } \\
\text { bawahan dari } \\
\text { karyawan } \\
\text { lain yang } \\
\text { memiliki } \\
\text { jabatan yang } \\
\text { sama dan } \\
\text { pengguna } \\
\text { tidak } \\
\text { memiliki } \\
\text { bawahan }\end{array}$ & $\begin{array}{l}\text { - Pengguna tidak memiliki } \\
\text { bawahan } \\
\text { - Ada karyawan lain yang } \\
\text { memiliki jabatan dan divisi } \\
\text { yang sama } \\
\text { - Karyawan lain tersebut } \\
\text { memiliki bawahan } \\
\text { - Ada task yang ditugaskan } \\
\text { kepada pengguna } \\
\text { - Pengguna sudah berada di } \\
\text { halaman task activity dan } \\
\text { pada tab assigned to me }\end{array}$ & $\begin{array}{l}\text { 1. Pilih task yang } \\
\text { ditugaskan } \\
\text { 2. Klik tombol Assign } \\
\text { 3. Pilih nama } \\
\text { bawahan dari } \\
\text { karyawan lain yang } \\
\text { memiliki jabatan dan } \\
\text { divisi yang sama } \\
\text { pada field Assign To } \\
\text { 4. Pilih On Progress } \\
\text { pada field Status } \\
\text { 5. Klik Send }\end{array}$ & $\begin{array}{l}\text { Nama bawahan } \\
\text { karyawan lain } \\
\text { tidak muncul dan } \\
\text { tes tidak dapat } \\
\text { dilanjutkan pada } \\
\text { step } 3\end{array}$ & $\begin{array}{l}\text { Muncul pesan } \\
\text { "Success Update." } \\
\text { dan task hilang } \\
\text { dari tab assigned } \\
\text { to me }\end{array}$ & High \\
\hline $\begin{array}{l}\text { Mencari task } \\
\text { yang sudah } \\
\text { diselesaikan } \\
\text { berdasarkan } \\
\text { jenis project } \\
\text { dan } \\
\text { diurutkan } \\
\text { berdasarkan } \\
\text { tanggal task }\end{array}$ & $\begin{array}{l}\text { - Ada lebih dari satu task } \\
\text { yang sudah diselesaikan } \\
\text { dengan jenis project yang } \\
\text { sama } \\
\text { - Pengguna sudah berada di } \\
\text { halaman task activity dan } \\
\text { pada tab resolved activity }\end{array}$ & $\begin{array}{l}\text { 1. Pilih Project Name } \\
\text { pada form pencarian } \\
\text { 2. Pilih Task Target } \\
\text { Date pada field Sort } \\
\text { By } \\
\text { 3. Ketikan jenis } \\
\text { project yang sudah } \\
\text { ada pada field Search } \\
\text { 4. Klik tombol } \\
\text { dengan icon kaca } \\
\text { pembesar }\end{array}$ & $\begin{array}{l}\text { Muncul daftar task } \\
\text { dalam project } \\
\text { yang memiliki } \\
\text { jenis sesuai dengan } \\
\text { yang diketikan } \\
\text { pada kolom Search } \\
\text { dan sudah } \\
\text { diselesaikan, dan } \\
\text { diurutkan } \\
\text { berdasarkan } \\
\text { tanggal task }\end{array}$ & $\begin{array}{l}\text { Muncul daftar task } \\
\text { dalam project } \\
\text { yang memiliki } \\
\text { jenis sesuai dengan } \\
\text { yang diketikan } \\
\text { pada kolom Search } \\
\text { dan sudah } \\
\text { diselesaikan, tidak } \\
\text { berurut sesuai } \\
\text { dengan tanggal } \\
\text { task }\end{array}$ & Low \\
\hline
\end{tabular}


Modul laporan menghasilkan laporan berupa laporan task, laporan project, dan dashboard. Laporan task terdiri dari tiga laporan, yang mana menunjukkan task-task yang sedang ditugaskan, yang akan datang, dan yang telah diselesaikan oleh pengguna. Laporan project adalah laporan yang hanya dapat diakses oleh admin dan berisi data semua project yang terjadi dalam perusahaan. Dashboard berisi rangkuman dari jumlah semua project yang dilakukan setiap divisi dalam 30 hari terakhir, beserta total waktu keterlambatan dalam pengerjaan task untuk tiap divisi.

Modul pengguna berfungsi untuk memberikan batasan terhadap pengguna mengenai halaman apa saja yang dapat diakses. Modul ini juga meliputi fungsi login untuk aplikasi.

Client dan project baru dapat dibuat oleh semua divisi. Divisi admin bertanggung jawab untuk pengelolaan master data, serta melakukan validasi terhadap client dan project baru. Semua divisi lainnya berperan untuk menjalankan task yang ditugaskan kepada divisi tersebut.

Evaluasi akan dilakukan pada kelima modul tersebut. Evaluasi adalah proses mengeksekusi suatu program dengan tujuan utama menemukan kesalahan. Evaluasi aplikasi BAM pada karakteristik functional suitability menggunakan instrumen test case. Test case adalah seperangkat masukan untuk diuji, kondisi untuk dieksekusi, dan hasil yang diharapkan. Test case dalam penelitian ini ditujukan untuk memastikan fungsi yang dibutuhkan dapat berjalan sesuai dengan requirement. Test case juga ditujukan sebagai mekanisme yang dapat membantu memastikan kelengkapan tes dan menyediakan kemungkinan tertinggi untuk menangkap kesalahan yang ada dalam aplikasi.

Testing pada modul project bisnis dan penugasan pada sub-karakteristik F2 menunjukkan ada beberapa test case yang tidak terpenuhi karena adanya ketidaksesuaian antara hasil yang diharapkan dan hasil yang sebenarnya, hasil yang tidak sesuai dapat dilihat pada Tabel 2. Kolom test case menunjukkan kasus yang diuji. Kolom precondition berisi kondisi yang harus dipenuhi sebelum test case dijalankan. Kolom test step menunjukkan langkahlangkah yang dilakukan untuk menguji test case. Kolom expected result menunjukkan hasil yang diharapkan dalam kasus yang diberikan. Kolom actual result menunjukkan hasil yang didapatkan setelah menjalankan test step. Kolom severity menunjukkan tingkat keparahan dari ketidaksesuaian. Beberapa kolom seperti status, error description, remark, dan sign tidak ditampilkan karena adanya keterbatasan dalam penulisan paper ini.

Ada beberapa ketidaksesuaian lainnya dengan tingkat keparahan rendah yang ditemukan pada modulmodul lainnya. Dari ketiga sub-karakteristik, subkarakteristik F2 merupakan karakteristik dengan jumlah ketidaksesuaian tertinggi dengan jumlah ketidaksesuaian sebanyak $62,5 \%$ dari semua ketidaksesuaian. Jumlah ketidaksesuaian yang ditemukan dari tiap karakteristik dapat dilihat pada Tabel 3. Dari kelima modul, modul penugasan memiliki jumlah ketidaksesuaian paling tinggi dengan jumlah $37,5 \%$.
Tabel 3. Jumlah Ketidaksesuaian yang Ditemukan

\begin{tabular}{ccccc}
\hline \multirow{2}{*}{ Modul } & \multicolumn{3}{c}{ Sub-karakteristik } & \multirow{2}{*}{ Persentase } \\
\cline { 2 - 4 } & F1 & F2 & F3 & \\
\hline Master & 0 & 1 & 0 & $12,5 \%$ \\
\hline $\begin{array}{c}\text { Project } \\
\text { Bisnis }\end{array}$ & 0 & 1 & 0 & $12,5 \%$ \\
\hline Penugasan & 1 & 2 & 0 & $37,5 \%$ \\
\hline Laporan & 1 & 1 & 0 & $25 \%$ \\
\hline Pengguna & 0 & 0 & 1 & $12,5 \%$ \\
\hline Persentase & $25 \%$ & $62,5 \%$ & $12,5 \%$ & $100 \%$ \\
\hline
\end{tabular}

\section{Kesimpulan}

Dari hasil testing, dapat disimpulkan bahwa aplikasi BAM yang digunakan masih memiliki beberapa ketidaksesuaian dengan hasil yang diharapkan. Tanpa dilakukannya testing, perusahaan tidak akan tahu bahwa ada beberapa kasus dalam aplikasi yang tidak sesuai dengan harapan perusahaan dan berpotensi menggangu proses bisnis perusahaan.

Secara kesuruhan, selain beberapa ketidaksesuaian tersebut, aplikasi telah memenuhi karakteristik functional suitability dalam ketiga sub-karakteristik F1, F2, dan F3 dari standar ISO 25010, sehingga aplikasi BAM masih layak digunakan dari sisi fungsional jika ketidaksesuaian tersebut dapat segera diperbaiki, terutama untuk ketidaksesuaian yang memiliki tingkat keparahan tinggi dan menengah. Testing lebih lanjut dalam karakteristik lainnya masih perlu dilakukan untuk mengukur kelayakan aplikasi secara menyeluruh.

Metode testing UAT yang digunakan juga dinilai tepat oleh peneliti karena dapat mencakup area yang luas dari aplikasi dari sisi fungsional.

\section{Daftar Pustaka}

[1] Y. Hasan Al-Mamary, A. Shamsuddin, dan N. Aziati, "The Role of Different Types of Information Systems In Business Organizations: A Review," Int. J. Res., 2014.

[2] D. A. Almazán, Y. S. Tovar, dan J. M. M. Quintero, "Influence of Information Systems on Organizational Results," Contaduría y Adm., 2017.

[3] L. Mishra, R. Kendhe, dan J. Bhalerao, "Review on Management Information Systems (MIS) and its Role in Decision Making," Int. J. Sci. Res. Publ., 2015.

[4] A. Vera-Baquero, R. Colomo-Palacios, dan O. Molloy, "Real-time Business Activity Monitoring and Analysis of Process Performance on BigData Domains," Telemat. Informatics, 2016.

[5] F. M. Nafie dan M. A. Eltahir, "Real-Time Monitoring and Analyzing Business Process Performance," vol. 6, no. 7, hal. 31-35, 2016.

[6] J. G. Kariuki, "An Exploration of the Guiding Principles, Importance and Challenges of Monitoring and Evaluation of Community Development Projects and Programmes," Int. J. Bus. Soc. Sci., vol. 5, no. 1, hal. 140-147, 2014. 
[7] F. M. Al Obisat, Z. T. Alhalhouli, T. I. Alrawashdeh, dan T. E. Alshabatat, "Review of Literature on Software Quality," World Comput. Sci. Inf. Technol. J., vol. 8, no. 5, hal. 32-42, 2018.

[8] A. E. Dreheeb, N. Basir, dan N. Fabil, "Impact of System Quality on Users' Satisfaction in Continuation of the Use of e-Learning System," Int. J. e-Education, e-Business, e-Management eLearning, 2016.

[9] J. F. Andry, J. S. Suroso, dan D. Y. Bernanda, "Improving Quality of SMEs Information System Solution with ISO 9126," J. Theor. Appl. Inf. Technol., 2018.

[10] J. H. Yahaya, A. Tareen, A. Deraman, dan A. Razak Hamdan, "Software Quality and Productivity Model for Small and Medium Enterprises," Int. J. Adv. Comput. Sci. Appl., vol. 8, no. 5, hal. 316-320, 2017.

[11] I. Saptarini, S. Rochimah, dan U. L. Yuhana, "Security Quality Measurement Framework for Academic Information System ( AIS ) Based on ISO / IEC 25010 Quality Model," in The 2nd International Seminar on Science and Technology, 2016, hal. 128-135.

[12] A. Idri, L. Sardi, dan J. L. Fernández-Alemán, "Quality evaluation of gamified blood donation apps using ISO/IEC 25010 standard," in HEALTHINF 2018 - 11th International Conference on Health Informatics, Proceedings; Part of 11th International Joint Conference on Biomedical Engineering Systems and Technologies, BIOSTEC 2018, 2018, hal. 607614.

[13] A. A. Ouassarah, N. Aversengy, X. Fournety, J. M. Petit, R. Revol, dan V. M. Scuturici, "Understanding Business Trends from Data Evolution with Tornado," in Proceedings International Conference on Data Engineering, 2015.
[14] Haslinda et al., "Evaluation of e-Book Applications Using," in 2015 International Symposium on Technology Management and Emerging Technologies (ISTMET), 2015, no. August 2015, hal. 114-118.

[15] H. Setiawan, "Analisis Kualitas Sistem Informasi Pantauan Pembentukan Karakter Siswa di SMK N 2 Depok Sleman," Elinvo (Electronics, Informatics, Vocat. Educ., 2017.

[16] J. P. Miguel, D. Mauricio, dan G. Rodríguez, “A Review of Software Quality Models for The Evaluation of Software Products," Int. J. Softw. Eng. Appl., 2014.

[17] ISO/IEC, "ISO/IEC 9126-1:2001 - Software engineering -- Product quality -- Part 1: Quality model," Software Process: Improvement and Practice. 2001.

[18] ISO; IEC, "Software Engineering — Software Product Quality Requirements and Evaluation (SQuaRE) - Data Quality Model (ISO/IEC 25012:2008(E))," ISO/ IEC. 2008.

[19] IEEE, "IEEE Standard Glossary of Software Engineering Terminology (IEEE Std 610.121990). Los Alamitos," CA IEEE Comput. Soc., 1990.

[20] E. V. Sandin, N. M. Yassin, dan R. Mohamad, "Comparative Evaluation of Automated Unit Testing Tool for PHP," Int. J. Softw. Eng. Technol., vol. 03, no. 2, hal. 7-11, 2016.

[21] D. W. Utomo, D. Kurniawan, dan Y. P. Astuti, "Teknik Pengujian Perangkat Lunak dalam Evaluasi Sistem Layanan Mandiri Pemantauan Haji pada Kementerian Agama Provinsi Jawa Tengah," Simetris J. Tek. Mesin, Elektro dan Ilmu Komput., 2018.

[22] S. V. Pathak, "Acceptance Testing Technique: A Survey Along with Its Operating Frameworks," Int. J. Recent Innov. Trends Comput. Commun., vol. 4, no. 4, hal. 772-775, 2016. 